\title{
PERLINDUNGAN HUKUM TERHADAP KREDITUR SEPARATIS MENURUT UNDANG UNDANG NOMOR 37 TAHUN 2004 TENTANG KEPAILITAN DAN PENUNDAAN KEWAJIBAN PEMBAYARAN UTANG
}

\author{
Ramadhan Muhammad (1), Ni Putu SawitriNandari (2) \\ ramadhan25id@gmail.com ${ }^{(1)}$, sawitrinandari@gmail.com ${ }^{(2)}$
}

\section{Universitas Pendidikan Nasional}

\begin{abstract}
Entering the era of the 1990s the Indonesian economy increased its gains in the business world, but increasing the era of the 1990s the business world in ASEAN increased Indonesia increased the prolonged budget, companies in finance and banking became bankrupt Anything that could be used to pay its debts to creditors and many the companies that had problems at the time, Bankruptcy could occur with the rapid development of finance and trade so that it appeared mixed. In the business world, it can happen that one party cannot carry out its obligations to pay its debts to the other party, so a confiscation of the assets of the company must occur to repay the debt after causing a lawsuit by the creditor to the court, in this case often too referred to as going bankrupt against the company (debtor). Separating creditors are mortgage holders, fiduciary ownership, mortgage rights, mortgages and other material collateral. It is said "separator" connotes "separator" because the creditor's position is from other creditors, and the delivery is separate from public bankrupt assets. The purpose of this study is to study the legal protection required by separate creditors for debtors in bankruptcy cases according to the Bankruptcy Law number 37 of 2004. The method used in this study is the normative legal research method. This study found how to protect the law of any separatist creditor and the obligations that obtained a separatist creditor in a bankruptcy case.

Keywords: Legal Protection, Separatist Creditor, Bankruptcy,
\end{abstract}

\begin{abstract}
ABSTRAK
Memasuki era tahun 1990 perokonomian Indonesia mengalami peningkatan dalam dunia usahanya, Namun memasuki pertengahan era tahun 1990 dunia usaha di ASEAN terutama Indonesia mengalami krisis moneter yang berkepanjangan,perusahaan di bidang keuangan dan perbankan menjadi bankrut yaitu tidak mampu untuk membayar utangutangnya kepada kreditur dan banyak perusahaan-perusahaan bermasalah di pailitkan pada saat itu, Kepailitan bisa terjadi dengan makin pesatnya perkembangan perekonomian dan perdagangan sehingga muncul bermacam - macam permasalahan utang piutang yang timbul. Pada dunia bisnis dapat terjadi salah satu pihak tidak dapat melakukan kewajibannya membayar utang-utangnya kepada pihak lain sehingga mengakibatkan terjadi penyitaan atas harta (aset) perusahaan untuk melunasi utang tersebut setelah adanya gugatan oleh pihak yang berpiutang (kreditur) ke pengadilan dalam hal ini sering juga disebut dengan terjadi pailit terhadap perusahaan (debitur). Kreditur separatis adalah Kreditur pemegang Gadai,jaminan Fidusia, hak Tanggungan, Hipotek dan agunan kebendaan lainnya.Dikatakan "separatis" yang berkonotasi "pemisah" karena kedudukan Kreditur tersebut memang dipisahkan dari kreditur lainnya,dalam arti dia dapat menjual sendiri dan mengambil sendiri hasil penjualan, yang terpisah dengan harta pailit umumnya. Tujuan dari
\end{abstract}


penelitian ini adalah Untuk mengetahui perlindungan hukum yang dimiliki kreditur separatis terhadap debitur dalam kasus kepailitan menurut Undang-Undang kepailitan nomor 37 tahun 2004. Metode yang digunakan dalam penelitian ini adalah metode penelitian hukum normatif. Penelitian ini menemukan bagaimana perlindungan hukum kreditur separatis apa hak dan kewajiban yang di dapatkan kreditur separatis dalam kasus kepailitan.

Kata Kunci: Perlindungan Hukum, Kreditur Separatis, Kepailitan.

\section{PENDAHULUAN}

Memasuki era tahun 1990 perokonomian Indonesia mengalami peningkatan dalam dunia usahanya. Kurs rupiah cenderung bagus dan dunia usaha semakin maju, Investor asing yang ada di Indonesia semakin nyaman untuk mengembangkan sayap nya dalam dunia usaha di Indonesia, Namun memasuki pertengahan era tahun 1990 dunia usaha di ASEAN terutama Indonesia mengalami krisis moneter yang berkepanjangan.

Pada saat itu krisis moneter mennyebabkan dunia usaha khususnya Indonesia mengalami keterpurukan dimana harga barang melonjak naik, rupiah merosot turun sehingga perusahaan-perusahaan yang ada di Indonesia khususnya di bidang keuangan dan perbankan menjadi bankrut yaitu tidak mampu untuk membayar utang-utangnya kepada kreditur dan banyak perusahaan-perusahaan bermasalah dan di pailitkan pada saat itu.

Kepailitan bisa terjadi dengan makin cepatnya laju perekonomian dan perdagangan sehingga timbul bermacam - macam kendala utang piutang yang muncul dalam rangka memajukan kuwalitas modal atau kinerja suatu perusahaan.. Di dunia bisnis bisa terjadi suatu peristiwa salah satu orang yang terkait tidak dapat melakukan tugasnya membayar utangutangnya kepada pihak lain sehingga mengakibatkan terjadi penyitaan atas harta atau asset perusahaan untuk melunasi utang berikut sesudah adanya gugatan oleh orang yang berpiutang (kreditor) ke pengadilan dalam hal ini kerap juga disebut juga dengan berlaku pailit terhadap perusahaan (debitor).

Pada hakikatnya kepailitan mencakup seluruh kekayaan debitur pada waktu pernyataan pailit tersebut dilakukan bersama semua aset yang didapatkan selama proses kepailitan. Dengan dinyatakannya pailit, debitur pailit demi hukum akan kehilangan hak- haknya untuk memiliki dan memproses kekayaannya yang dibawa dalam kepailitan, terhitung semenjak asetnya yang dimasukkan dalam kepailitan, terhitung semenjak 
hari kepailitan itu. Pasal 25 UUK dan PKPU menegaskan bahwa "sem perikatan debitur pailit yang dilaksanakan setelah dinyatakan pailit tidak bisa dibayar dari harta pailit kecuali jika perikatan-perikatan tersebut mendatangkan keuntungan bagi harta kekayaan i Oleh karena itu gugatangugatan hukum yang berasal pada hak dan kewajiban harta kekayaan debitor pailit harus diajukan terhadap kurator. Begitupun segala gugatan hukum dengan tujuan untuk memenuhi perikatan dari harta pailit selama dalam kepailitan, walaupun diajukan terhadap debitur pailit Memahami Undang-Undang Nomor 37 sendiri, hanya dapat diajukan dengan laporan atau pencocokannya.

Peningkatan arus moneter yang berlangsung di berbagai negara di benua Asia, termasuk Indonesia sejak pertengahan tahun 1997 telah membawa pengaruh pada kegiatan ekonomi dunia pada umumnya dan nasional pada khususnya terutama kemampuan dunia usaha untuk mempertahankan kegiatan usahanya, bahkan termasuk kemampuannya untuk memenuhi kewajiban pembayaran terhadap para kreditornya. Dalam dunia hukum, debitor yang tidak bisa melengkapi kewajibannya terhadap kreditur bisa diputuskan pailit. Tujuan yang paling utama dari kepailitan yaitu untuk dapat dilakukannya pembagian diantara para kreditor atas kekayaan debitor oleh kurator. sehingga tidak ada terjadinya sitaan terpisah yang di sebut eksekusi terpisah dengan Kreditur dan digantikan dengan menyelenggarakan sitaan bersama agar kekayaan debitur bisa dibagi rata kepada seluruh kreditor bersamaan dengan hak masing - masing, itu lah tujuan dari Kepailitan ini ${ }^{1}$.

Pailit, Failliet (menurut bahasa belanda), atau bankrupt,(dalam bahasa inggris).Pailit pada masa hindia- belanda tidak meliputi ke dalam KUH Dagang Wetboek van koopandle dan telah di terapkan dalam peraturan tersendiri ke dalam faillissements-verordering, sejak 1906 yang dahulu ditujukana bagi pedagang saja tetapi selanjutnya bisa digunakan untuk golongan manapun. kasus pailit sebagaimana peraturan lainnya, dirasakan sangat penting keberadaannya. Tahun 1997,ketika krisis ekonomi melanda Indonesia diamana hampir seluruh sendi kehidupan Perokonomian nasional rusak. Dari Krisis tersebut membawa perubahan

1 Sutan Remy Sjahdeini, 2009, Hukum Kepailitan: Memahami UndangUndang Nomor 37 Tahun 2004 Tentang Kepailitan,Pustaka Utama Grafiti, Jakarta, h.22. 
yang sangat Signifikan bagi perkembangan peraturan kepailitan di Indonesia. $^{2}$

Pailit adalah suatu kejadian dimana debitur tidak dapat untuk melakukan pembayaran - pembayaran kepada utang - utang dari pada krediturnya. peristiwa tidak dapat membayar biasanya dikarenakan kesulitan kondisi finansial dari usaha debitur yang sudah mendapati kemunduran ${ }^{3}$. Kepailitan merupakan salah satu cara untuk menyelesaikan sengketa utang piutang. Lembaga ini bukan untuk penyelesaian utang seorang kreditur melainkan untuk kepentingan sejumlah kreditur. Dengan dijatuhkan putusan pailit, maka kreditur-kreditur lainnya dapat beramairamai mengajukan tagihan utangnya. Syarat - syarat seorang debitur dapat diputuskan pailit dari pengadilan berdasarkan debitur itu mempunyai minimal dua orang kreditur dan paling sedikit satu utang yang sudah jatuh tempo dan bisa di tagih tidak di bayar lunas ${ }^{4}$.

Maka diadakanlah penyempurnaan terhadap peraturan tersebut dengan Perpu Nomor 1/1998 berdasarkan Perubahan Atas UU Tentang Kepailitan yang diundangkan pada tanggal 22 April 1998 melalui Lembaran Negara RI Nomor 87/1998. Penyempurnaan ini sedikit banyak karena ada desakan dari International Monetary Found (IMF). Perpu Nomor 1/1998 tentang Perubahan Atas Undang-undang Tentang Kepailitan ini disempurnakan dengan beberapa perubahan ketentuan kemudian ditetapkan menjadi Undang-undang dengan UU No 4 Th 1998 Tentang Penetapan Peraturan Pemeritah Pengganti Undang-undang Nomor 1 Tahun 1998. Tahan kepailitan diawali dengan adanya permohonan pailit terhadap debitur yang memenuhi syarat, sesuai Pasal 2 ayat 1 UU No 37 Th 2004 tentang Kepailitan dan PKPU (selanjutnya disebut UndangUndang Kepailtan) yang menyatakan bahwa :

"Debitur yang memiliki dua atau lebih Kreditur dan tidak melunasi sedikitnya satu utang yang telah jatuh tempo dan bisa ditagih, dinyatakan pailit melalui putusan pengadilan, baik atas keinginannya sendiri maupun atas tuntutan satu atau lebih dari krediturnya."

2 Abdul R. Saliman, 2011, Hukum Bisnis Untuk Perusahaan Teori Dan Contoh Kasus, Kencana, Jakarta.h.118.

3 Hadi Shubhan, 2008, Hukum Kepailitan Prinsip,Norma,Dan Praktik Di Peradilan, Kencana,Jakarta,h. 1.

Piutang,Kencana,Jakarta,h.113. Supramono, 2013, Perjanjian Utang 
Setelah terpenuhi syarat yang ditentukan di atas, jadi permohonan pailit atas debitur tersebut, bisa diserahkan oleh satu atau lebih krediturnya ke Pengadilan Niaga, yang adalah badan peradilan yang memiliki kehendak untuk memproses, memeriksa dan mengadili kasus kepailitan. Jika permohonan pailit itu diidahkan maka Pengadilan Niaga akan mengumumkan putusan yang memutuskan debitur dalam keadaan pailit.

Dari yang penulis baca dan teliti penulis menyimpulkan adanya konflik norma pada Undang - Undang Kepailitan dari pasal 55 dan 56 terjadi konflik norma interen dan dengan penelitan yang di lakukan penulis dapat di perbaikinya sistem hukum pada Undang - Undang tersebut.

Pasal 55 ayat (1) "dean tetap memperhatikan ketentuan sebagaimanaa dimaksud dalam Pasal 56, Pasal 57, dan Pasal 58, setiap Kreditor pemegang gadaii, jaminan fidusia, hak tangungan, hipotik, atau hak agunan atas kebendaan yang lain, dapat memproses haknya seolaholah tidak terjadi kepailitan."

Pasal 56 ayat (2) "Hak eksekusi Kreditur sebagaimana diartikan dalam Pasal 55 ayat (1) dan hak pihak ketiga untuk menuntut asetnya yang ada dalam penguasaan Debitur Pailit atau Kurator, ditangguhkan untuk rentang waktu maksimal 90 (sembilan puluh) hari semenjak tanggal pengumuman pernyataan pailitt diucapkan"

Dari apa yang penulis dapatkan terjadi konflik norma di antara 2 pasal tersebut, yaitu ketidak pastian hukum hak Kreditur separatis dalam mengeksekusi jaminan yang dimilikinya atas debitur.

Kreditur separatis iyalah Kreditur pemegang Gadai,jaminan Fidusia, hak Tanggungan,Hipotek dan agunan kebendaan lainnya.Dikatakan "separatis" yang berkonotasi "pemisah" karena kedudukan Kreditur tersebut memang berbeda dari kreditur lainnya,dalam arti dia dapat menjual sendiri dan mengambil sendiri hasil penjualan, yang terpisah dengan harta pailit umumnya.

Penyelesaian utang lewat lembaga kepailitan ditujukan untuk mendapatkan pembagian yang adil bagi para kreditur. tetapi bagi kreditur separatis (pemegang gadai, jaminan fidusiia, hak tanggungan, hipotek dan agunan kebendaan lainnya), adanya ketentuan penangguhan eksekusi dan pembatasan jangka waktu eksekusi jaminan dalam UU Kepailitan tidak 
terlalu selaras dengan ketentuan hukum jaminan, sehingga dapat mempunyai potensi merugikan kreditor separatis. pada pembahasan tulisan ini bisa di ambil kesimpulan bahwa perlu dilakukan suatu penyesuaian baik melalui revisi undang-undang maupun dengan Peraturan Pemerintah, sehingga bisa memberikan kepastian hukum tentang ada atau tidak adanya hak eksekusi kreditor separatis ${ }^{5}$.

Berdasarkan latar belakang tersebut, Adapun rumusan masalah yang dapat diangkat adalah sebagai berikut: Bagaimanakah perlindungan hukum kreditur separatis terhadap debitur dalam kasus kepailitan menurut UU kepailitan nomor 37 Th 2004 KPKPU.

\section{METODE PENELITIAN}

Adapun jenis penelitian penulis pergunakan adalah jenis penelitian Normatif yaitu penelitiaan yang mengkaji Studi kepustakaan (Libary Reaserch). Dalam metode ini penulis melakukan pengumpulan bahan hukum seperrti Peraturan Perundang - undangan, Literatur yang berkaitan dengan Perlindungan Hukum terhadap Kreditur Separatis dalam hal Kepailitan. Jenis bahan hukum menurut sumbernya yang dipergunakan dalam penulisan ini adalah: bahan Hukum Premier adalah bahan hukum yang meliputi peraturan-peraturan yang berhubungan dengan masalah yang diteliti yaitu KUH Perdata pasal 1131 sampai dengan 1133, UndangUndang Negara Republik Indonesia No 37 tahun 2004 tentang tentang kepailitan dan PKPU, pasal 55,56, 222 ayat (3), Peraturan Pemerintah Republik Indonesia nomor 10 tahun 2005 tentang Penghitungan, Jumlah Hak Suara Kreditor. Bahan Hukum Skunder adalah bahan hukum yang meliputi berbagai literatur, Seperti Buku - Buku ,Jurnal , bahan ajar, dan artikel yang di dapat dari (internet). Bahan Hukum Tersier adalah bahan hukum yang berasal dari Kamus Besar Bahasa Indonesia dan Kamus Hukum. Teknik pengumpulan data yang dipergunakan dalam penelitian ini adalah tehnik dokumentasi yakni dengan pengumpulan bahan hukum yang dilakukan melalui membaca, mencatat, peraturan perundang udangan,kamus besar bahasa Indonesia, buku-buku literature, artikelartikel (internet) yang berkaitan dengan obyek permasalahan yang hendak

5 https://www.mendeley.com/catalogue/perlindu ngan-hukum-krediturseparatis-dalam-kepailitan/ diakses pada 26 Februari pukul 20:57 Wita 
diteliti. Teknik analisis data yang penulisan pergunakan dalam penulisan ini adalah tehnik deskriptif kualitatif, yaitu dengan menjelaskan,menguraikan , menggambarkan dan/atau menjabarkan berdasarkan data-data dan teoriteori yang didapat melalui buku-buku kepustakaan internet, serta Peraturan Perundang-Undangan yang berkaitan dengan Perlindungan Hukum Kreditur separatis dalam kepailitan undang undang no . 37 thn 2004 PPKPU.

\section{HASIL PENELITIAN DAN PEMBAHASAN}

Setiap subjek hukum selalu membutuhkan perlindungan hukum dalam pergaulan hidup di dalam bermasyarakat. Tidak terlepas para kreditur yang mempunyai piutang terhadap dibiturnya. Di Indonesia telah diatur tata cara dalam kepailitan yang di atur dalam undang- undang.

Perlindungan Hukum dalam kamus besar bahasa Indonesia (KBBI) adalah, kata perlindungan menurut KBBI berarti tempat berlindung atau adalah Jasa perbuatan melindungi , misalnya memberikan perlindungan terhadap orang yang membutuhkan. Dan Hukum berarti peraturan yang dibuat dari penguasa atau pemerintah atau adat yang berlaku bagi semua orang dalam suatu masyarakat.

Jadi perlindungan hukum berarti perbuatan hal yang bersifat melindungi subyek-subyek hukum dengan kumpulan peraturan perundangundangan yang berlaku dan pelaksaannya dapat dipaksakan dan berlaku sanksi di dalamnya.

Negara Indonesia adalah Negara hukum berdasarkan pada Pancasila wajiblah memberikan perlindungan hukum terhadap masyarakatnya yang sesuai dengan Undang - Undang . Oleh karenanya perlindungan hukum berdasarkan pada Undang - Undang dan Pancasila berarti pengakuan dan pelindungan hukum akan harkat martabat manusia atas dasar nilai ketuhanan, kemanusiaan ,persatuan, permusyawaratan dan keadilan sosial.

Kreditur separatis adalah salah satu kreditur yang hak nya di istimewakan dalam kasus kepailitan di Indonesia Karena memiliki jaminan kebendaan dan yang lainnya, hak istimewa tersebut seperti tidak terpengaruhnya kreditur ini ats putusan pailit dari debitornya dimana kreditur ini dapat tepat mengekskusi jaminan tersebut tetapi harus tetap 
mengikuti aturan yang ada di Indonesia terkait haknya tersebut.

Dari ketentuan pasal 1 angka 1 UUK-PKPU yang dimaksud dengan debitur ialah: "Debitur adalah orang yang mempunyai utang karena perjanjian atau undang-undang yang pelunasannya dapat di tagih di muka pengadilan."

Kepailitan yang di alami sebuah perseroan terbatas yang selanjutnya di singkat PT atau Debitur dapat terjadi, dalam hal kondisi pasiva PT lebih besar daripada aktiva PT yang disebabkan kesulitan keuangan atau usaha perusahaan yang sedang mengalami keterpurukan. Sehingga perseroan terbatas tidak dapat untuk membayar utang perseroan yang sudah jatuh tempo dan para kreditor menuntut atas pembayaran piutang tersebut melalui lembaga kepailitan sebagai salah satu solusi untuk menyelesaikan utang piutang di antara Debitor dan para Kreditornya Perseroan Terbatas yang dinyatakan pailit oleh Pengadilan Niaga, bukan berarti Perseroan Terbatas tersebut dinyatakan bubar atau berakhirnya status badan hukum, sehingga perseroan masih mempunyai wewenang untuk melakukan perbuatan hukum. Kepailitan tidak berhubungan dengan status Perseroan sebagai badan hukum, melainkan hanya berhubungan dengan harta kekayaan Perseroan saja sebagai kekayaan perusahaan. Direksi perusahaan tetap dapat menjalankan perusahaan dan dapat melakukan perbuatan hokum yang menyangkut hak dan kewajibannya, selama tidak berhubungan dengan pengurusan dan pemberesan berkenaan dengan kekayaan Perseroan ${ }^{6}$.

Pernyataan kepailitan mengakibatkan kekayaan perseroan masuk dalam harta pailit yang berada dibawah penyitaan umum (sita umum). Menurut Pasal 21 UUKPKPU, harta pailit mencakup seluruh harta debitor pada saat putusan pailit diumumkan serta semua yang diperoleh debitor pailit selama kepailitan (kecuali yang secara tegas dinyatakan oleh Undang- Undang Kepailitan telah keluar dari harta pailit.) ${ }^{7}$

tugas untuk mengurus dan membereskan harta Debitor Pailit di bawah pengawasan Hakim Pengawas. Pengurusan harta pailit dimulai sejak adanya putusan pailit, dihitung sejak pukul 00.00 waktu setempat.

6 Etty Susilowati, 2011, Hukum Kepailitan Dan Penundaan Kewajiban Pembayaran Utang, Badan Penerbit Undip Press, Semarang, h. 109.

7 Sutan Remy, 2009, Hukum Kepailitan Memahami UU no 37 th 2004 KPKPU, Pustaka Utama Grafiti, Jakarta, h. 193. 
Sedangkan pemberesan harta pailit yang baru dapat dilakukan setelah Debitor pailit benar-benar dalam keadaan tidak lagi mampu membayar atau insolvensi setelah adanya putusan pernyataan pailit.

Berdasarkan ketentuan pada Pasal 178 ayat (1) UU Kepailitan, insolvensi baru dapat terjadi apabila: Jika pada rapat pencocokan piutang tidak direkomendasikan rencana perdamaian; Jika ada penawaran Berdamai oleh orang yang pailit maupun oleh kurator, tetapi para Kreditor dalam rapat verifikasi tidak menyetujuinya (pencocokan piutang); dan Apabila terdapat perdamaian dan disetujui oleh para Kreditor dalam rapat verifikasi tetapi pengesahan perdamaian tidak di setujui berdasarkan putusan yang sudah memperoleh kekuatan hukum tetap.

Kurator harus mengambil keputusan yang paling baik untuk memaksimalkan harga aset dalam proses pelunsan harta pailit. Dalam melaksanakan penjualan harta Debitor pailit, kurator harus memperhatikan beberapa hal, diantaranya adalah: Harus menjual untuk harga yang paling tinggi; Harus mengambil keputusan apakah harta tertentu harus dijual segera dan harta yang lain harus disimpan lebih dahulu karena nilainya bisa lebih tinggi di kemudian hari; Harus memiliki inisiatif dalam mendapatkan nilai teratas atas harta Debitor pailit.

Kreditor separatis sebagai kreditor yang memegang hak agunan atas kebendaan yaitu pemegang gadai, hak tanggungan, jaminan fidusia, hipotek atau hak agunan atas kebendaan lainnya.

Berdasarkan peraturan perundangan, maka bisa dirincikan kedudukan kreditor separatis adalah sebagai berikut: Kedudukan untuk didahulukan bagi kreditor separatis, memberikan hak didahulukan pada pelunasan piutang dari pada kreditor - kreditor lainnya. Pasal 1133 KUH Perdata memberikan hak istimewa untuk didahulukan dalam hal pemegang jaminan gadai dan hipotek. Berdasarkan Pasal 1134 KUH Perdata, hak istimewa iyalah suatu hak yang oleh UU diberikan terhadap seorang yang berpiutang agar tingkatnya lebih tinggi daripada debitur berpiutang lainnya dalam kasus kepailitan tersebut, semata- mata berdasarkan sifat piutangnya. Gadai dan hipotek adalah lebih tinggi dari pada hak istimewa, kecuali pada hal-hal yang dimana oleh undang undang ditetapkan sebaliknya.

Peraturan perundangan diluar KUH Perdata juga memberikan 
kedudukan untuk didahulukan bagi kreditor separatis, salah satunya pada UU No. 4 Th 1996 tentang Hak Tanggungan. Kedudukan untuk didahulukan kreditor pemegang hak terdapat pada Pasal 1 angka 1 Undang - Undang Hak Tanggungan (UUHT) mengenai pengertian hak tanggungan yaitu:

Kreditor separatis, yaitu kreditor pemegang hak jaminan kebendaan inrem, yang dalam KUH perdata disebut dengan nama Gadai dan hipotek. Pada saat ini, system hukum jaminan Indonesia mengenal 4 (emapat) macam jaminan, antara lain: 1. Hipotek Hipotek diatur dalam pasal 1162 s.d pasal 1232 bab XXI KUH Perdata, yang pada saat ini hanya diberlakukan untuk kapal laut yang berukuran minimal $20 \mathrm{~m}$ kubik dan sudah terdaftar di syahbandar serta pesawat terbang. "terhadap kapalkapal demikian yang terdaftar di syahbandar, oleh pasal 314 KUHD selanjutnya diperlakukan sebagai kebendaan yang tidak bergerak, dan oleh sebab itu pula penjamin yang dapat diletakkan di atasnya pun hanya dalam bentuk hipotek. Adapaun bagi kapal-kapal yang tidak terdaftar dianggap sebagai kebendaan yang bergerak yang terhadapnya berlakulah ketentuan pasal 1977 KUH Perdata yang berlaku bagi benda-benda bergerak yang tidak berupa bunga maupun piutang yang tidak harus dibayar kepada pembawa. Dengan demikian,berarti terhadap kapal laut dengan ukuran kurang dari $20 \mathrm{~m}$ kubik isi kotor, yang tidak didaftarkan dapat digadaikan.berbeda dengan kapal laut, hingga saat ini di Negara kita belum mengatur mengenai sifatkebendaan dari pesawat terbang."

2. Gadai diatur dalam pasal 1150 s.d psal 1160 bab XX KUH perdata, yang dibelakukan terhadap benda- benda bergerak. Dalam system jaminan gadai, seorang pemberi gadai (debitur) wajib melepaskan penguasaan atas benda yang akan dijaminkan tersebut kepada penerima gadai (kreditor). 3 . Hak tanggungan diatur dalam UU No.4 tahun 1996 tentang hak tanggungan atas tanah beserta benda-benda yang memiliki kaitan dengan tanah, yang merupakan jaminan atas hak-hak atas tanah tertentu berikut kebendaan yang melekat di atas tanah. 4. Fidusia, Hak fidusia diatur dalam undang- undang No.42 tahun 1999 tentang jaminan fidusia, yang objek jaminannya berupa benda-benda yang tidak dapat dijaminkan dengan gadai,hipotek,dan hak tanggungan ${ }^{8}$.

\footnotetext{
8 Jono,2013, Hukum Kepailitan, Sinar grafika, Jakarta, h.8.
} 
UU 42 Th 1999 tentang Jaminan Fidusia memberikan hak mendahului pada kreditor separatis penerima fidusia yaitu terdapat pada Pasal 27 UUJF yang berbunyi: 1.orang yang menerima Fidusia mendapatkan hak yang didahulukan terhadap kreditor lainnya. 2. Hak yang Diutamakan atau di dahulukan sebagaimana dimaksud dalam ayat (1) adalah hak Penerima Fidusia untuk mengambil pelunasan piutangnya atas hasil eksekusi Benda yang menjadi obyek Jaminan Fidusia. 3. Hak yang diutamakan dari orang yang menerima Fidusia tidak hapus karena adanya putusan kepailitan dan atau likuidasi Pemberi Fidusia.

Ketentuan pasal tersebut menngartikan bahwa adanya kepailitan debitor tidak menghapus atau mempengaruhi penerima fidusia atau kreditor separatis untuk didahulukan dalam pelunasan piutangnya daripada kreditor lainnya dan berhak atas mengambil pelunasan dari hasil ekseksui objek jaminan fidusia.

Berdasarkan Pasal 59 ayat (2) UUKPKPU bahwa Kurator wajib menuntut diserahkannya benda yang jadi agunan agar selanjutnya dijual sesuai dengan cara sebagaimana diartikan dalam Pasal 185, tanpa mengambil hak dari Kreditor pemegang hak tersebut dari hasil penjualan agunan yang dimiliknya tersebut. Pasal itu menunjukkan bahwa walaupun eksekusi dilakukan oleh kurator, tetapi tidak mengurangi hak kreditor separatis, yaitu untuk didahulukan daripada kreditor lain dan mendapat pelunasan penuh atas piutangnya. Kreditor separatis sejatinya tetap berhak mendapatkan haknya secara penuh dari hasil penjualan jaminan utang yang dilakukan oleh kurator. Kedudukan untuk dipisahkan Dikatakan separatis yang berkonotasi "pemisahan" karena kedudukan kreditor tersebut memang terpisahkan dari kreditor lainnya dan objek jaminannya juga dipisah dari harta pailit. Adapun arti dari kedudukan untuk dipisahkan yaitu mengenai pelaksanaan hak eksekutorial atau eksekusi jaminan utang. Kedudukan kreditor separatis ini terdapat dalam ketentuan Pasal 55 ayat (1) UUKPKPU yang menyatakan bahwa dengan tetap memperhatikan ketentuan sebagaimana dimaksud dalam Pasal 56, Pasal 57, dan Pasal 58, setiap Kreditur pemegang gadai, jaminan fidusia, hak tanggungaan, hipotek, atau hak agunan atas kebendaan lainnya, dapat mengeksekusi haknya seolah-olah tidak terjadi kepailitan.

Ketentuan dari pasal tersebut menjelaskan bahwa jaminan 
kebendaan kreditor separatis terpisah dari harta kekayaan debitor yang berarti tidak berada di penguasaan kurator dan bisa dieksekusi sendiri oleh kreditor separatis dengan cara pelelangan umum. Kreditor separatis bisa menjual sendiri objek jaminan di muka umum dan atas hasil dari penjualan tersebut kemudian diambil guna melunasi piutangnya. Sehingga dapat diartikan dalam hal kepailitan debitor, pelunasan piutang kreditor separatis cukup terjamin dan terlindungi oleh hukum yang ada dan tidak menghilangkan hak eksekutorialnya tersebut.

Pelaksanaan hak eksekutorial bagi kreditor separatis terdapat pada Kitab Undang - Undang Hukum Perdata (KUH Perdata), peraturan perundangan mengenai jaminan kebendaan, serta diatur pula dalam UUKKPKPU antara lain: 1. Pelaksanaan hak eksekutorial dalam KUH Perdata, 2. Pelaksanaan hak eksekutorial pada peraturan perundangan mengenai jaminan kebendaan. 3. Pelaksanaan hak eksekutorial pada UU No 37 Tahun 2004 tentang Kepailitan dan PKPU Pasal 55 ayat (1) Undang - Undang Nomor 37 Tahun 2004 tentang Kepailitan dan PKPU.

Dalam praktek kepailitan di Indonesia, walaupun KUH Perdata, peraturan perundangan mengenai jaminan kebendaan, serta Undang Undang Kepailitan memberikan perlindungan hukum untuk pelaksanaan hak eksekutorial bagi kreditor separatis, tetapi pada kenyataannya hak eksekutorial tersebut tidak mudah untuk diterapkan. Hal ini disebabkan karena dalam proses kepailitan, seringkali kreditor separatis mengalami kendala- kendala yaitu adanya beberapa ketentuan dalam Undang-Undang Kepailitan yang memberikan pembatasan terhadap pelaksanaan hak eksekutorial bagi kreditor separatis. Oleh karena itu diperlukan revisi atau penyesuaian terhadap Undang- Undang Kepailitan agar memberikan kepastian hukum pada proses pelaksanaan kepailitan di indonesia termasuk perlindungan hukum terhadap pelaksanaan hak eksekutorial kreditur separatis.

\section{KESIMPULAN}

Berdasarkan hasil penelitian dan pembahasan dalam penulisan hukum ini tentang "perlindungan hukum kreditur separatis terhadap debitur dalam kasus kepailitan menurut UU kepailitan no 37 tahun 2004 KPKPU" dapat ditarik kesimpulan sebagai berikut : 
a. Kreditor separatis mempunyai kedudukan untuk didahulukan pelunasan piutangnya daripada kreditor lainnya dan kedudukan untuk dipisahkan piutang atau benda jaminannya dari harta/boedel pailit debitor. Berdasarkan kedudukan tersebut, kreditor separatis dapat melaksanakan hak eksekutorial dengan menjual benda jaminan di muka umum dan mengambil bagian dari hasil penjualan untuk pelunasan piutangnya.

b. Berdasarkan Pasal 55 ayat (1) UUKPKPU, kreditor separatis bisa mengeksekusi haknya seolah-olah tidak terjadi kepailitan.Tetapi pada prekteknya, pelaksanaan hak eksekutorial tersebut harus ditangguhkan selama 90 hari (masa stay) sebagaimana diatur pada Pasal 56 ayat (1) UUKPKPU.

c. Ketentuan mengenai penangguhan tersebut dinilai memberikan batasan dan ketidakpastian dengan ketentuan sebelumnya yaitu Pasal 55 ayat (1) UUKPKPU dimana kreditur separatis bisa mengeksekusi seakan akan tidak terjadi kepailitan. Hal ini menunjukkan eksekusi "seolaholah tidak terjadi kepailitan" itu mempunyai kekuatan atau tidak bisa dilakukan dan Pasal 55 ayat (1) UUKPKPU tidak memberikan perlindungan yang cukup bagi kreditor separatis untuk segera melaksanakan hak eksekutorialnya dalam kepailitan.

d. Berdasarkan Pasal 59 ayat (1) UUKPKPU, kreditor separatis dapat mengeksekusi haknya, setelah masa stay berakhir atau dimulainya keadaan insolvensi. Hak eksekusi dilakukan dalam jangka waktu paling lambat 2 (dua) bulan sesudah dimulainya keadaan insolvensi. Kreditor separatis yang telah melaksanakan hak eksekusinya harus memberikan pertanggung jawaban terhadap kurator tentang hasil penjualan dan menyerahkan sisa hasil dari penjualan setelah dikurangi nominal utang, bunga dan biaya kepada kurator. Dalam hal hasil penjualan tidak mencukupi untuk melunasi piutang, maka kreditor separatis bisa mengajukan tagihan pelunasan atas kekurangan tersebut dari harta pailit sebagai kreditor konkuren.

Adapun saran yang dapat diberikan adalah pertama, penangguhan eksekusi menimbulkan ketidakpastian dan batasan bagi hak eksekusi kreditor separatis, karena disatu sisi terdapat ketentuan dalam UndangUndang Kepailitan maupun hukum jaminan yang mengatur dapat melakukan eksekusi seakan akan tidak terjadi kepailitan tetapi disisi lain 
terdapat ketentuan yang menangguhkannya. Oleh karena itu perlu dilakukan revisi undang- undang untuk memberikan perlindungan dan kepastian hukum mengenai ada atau tidaknya hak eksekusi "seolah-olah tidak terjadi kepailitan" bagi kreditor separatis dan agar tidak terjadinya norma konflik pada UU no 37 th 2004 KPKPU.

Kedua, Jangka waktu yang ditetapkan oleh Undang-Undang Kepailitan kepada kreditor separatis untuk melaksanakan hak eksekutorialnya yaitu 2 (dua) bulan dirasa terlalu sempit, mengingat kreditor separatis harus menemukan penawaran dan menjual dengan nilai harga yang tinggi agar menguntungkan bagi kreditor separatis sendiri tetapi juga debitor. Apabila lewat jangka waktu tersebut maka jaminannya harus diserahkan kepada kurator. Oleh karena itu Perlu di lakukan revisi mengenai jangka waktu tersebut agar kreditor separatis diberikan waktu yang lebih lama dalam mempersiapkan kelengkapan administrative untuk melakukan eksekusi serta memperoleh harga jual yang tinggi dan dapat menutupi dari piutang tersebut. 


\section{DAFTAR PUSTAKA}

\section{Buku:}

Jono,2013, Hukum Kepailitan, Sinar grafika, Jakarta.

Remy,Sutan, 2009, Hukum Kepailitan Memahami UU no 37 th 2004 KPKPU, Pustaka Utama Grafiti, Jakarta.

Saliman,Abdul R., 2011, Hukum Bisnis Untuk Perusahaan Teori Dan Contoh Kasus, Kencana, Jakarta.

Sjahdein, Sutan Remy, 2009, Hukum Kepailitan: Memahami UndangUndang Nomor 37 Tahun 2004 Tentang Kepailitan,Pustaka Utama Grafiti, Jakarta.

Shubhan,Hadi, 2008, Hukum Kepailitan Prinsip,Norma,Dan Praktik Di Peradilan, Kencana,Jakarta.

Supramono,Gatot, 2013,Perjanjian Utang Piutang, Kencana,Jakarta,h.113.

Susilowati, Etty, 2011, Hukum Kepailitan Dan Penundaan Kewajiban Pembayaran Utang, Badan Penerbit Undip Press, Semarang.

\section{Peraturan Perundang-Undangan}

Undang - Undang No 27 Tahun 2004 Tentang Kepailitan Dan Penundaan Kewajiban Pembayaran Utang.

\section{Internet}

https://www.mendeley.com/catalogue/perlindu

ngan-hukum-krediturseparatis-dalam-kepailitan/ diakses pada 26 Februari pukul 20:57 Wita 